\title{
INOVATYVIŲ MOKYMO PRIEMONIŲ TAIKYMAS MOKANT ANGLŲ KALBOS
}

\author{
Renata Skučienė \\ Generolo Jono Žemaičio Lietuvos karo akademija
}

Anotacija. Inovatyvios mokymo priemonès skatina besimokančiuju tarpusavio, taip pat besimokančiuju ir mokytoju bendravima, taip didindamos ju motyvacija ir gerindamos mokymosi rezultatus (Daukilas, 2007).

Šio tyrimo tikslas - išanalizuoti inovatyviu mokymo priemoniu poveiki besimokančiuju motyvacijai anglu kalbos pratybose. Siekiant išsiaiškinti naudojamu inovatyviu mokymo priemoniu ịtaka besimokančiuju motyvacijai anglu kalbos pratybose, buvo atliktas tyrimas taikant anketinès apklausos ir statistinès duomenu analizès metodus. Tyrimas buvo atliekamas Generolo Jono Žemaičio Lietuvos karo akademijos Užsienio kalbu instituto Kauno užsienio kalbu mokymo skyriuje. Buvo apklausta 50 anglu kalbos besimokančiu ivvairiu lygiu kursu klausytojų. Atlikto tyrimo rezultatai atskleidè, kad tradicinès mokymo priemonès anglu kalbos užsiemimuose yra naudojamos dažniau nei inovatyvios, iš inovatyviu mokymo priemoniu dažniausiai naudojamas multimedijos projektorius ir internetas, rečiausiaimobilusis telefonas, elektroninis paštas ir elektroninis žodynas. Remiantis gautais tyrimo rezultatais galima teigti, kad inovatyvios priemones klausytojus labiau motyvuoja mokytis nei tradicinès. Klausytoju nuomone, inovatyvios mokymo priemonès turètu büti naudojamos dažniau nei $15 \%$ pamoku. Kaip labiausiai motyvuojančios inovatyvios mokymo priemonès buvo ìvertintas internetas, multimedijos projektorius ir kompiuterinés programos. Kita vertus, klausytojai teigia, kad tradiciniu mokymo priemoniu nereikètu visiškai atsisakyti. Iškelta hipotezè, kad inovatyvios mokymo priemonès labiau motyvuoja mokytis nei tradicinès, iš esmés pasitvirtino: $26 \%$ klausytoju visiškai sutiko, o $48 \%$ sutiko su šiuo teiginiu; su teiginiu, kad labiau motyvuoja mokytis tradicinès priemonès, visiškai sutiko $12 \%$, o sutiko $42 \%$ klausytojų.

Pagrindiniai žodžiai: inovatyvios mokymo priemonès, tradicinès mokymo priemonès, mokymosi motyvacija.

\section{Ivadas}

Vienas svarbiausių veiksmingos pamokos principų yra motyvacija. Tai - motyvai, paskatos veikti, judèti, susijusios su konkrečia situacija. Neabejotina, kad motyvacija yra nepaprastai svarbus sėkmingo mokymosi ir gerų rezultatų veiksnys. Be to, nepakanka vien pradinio motyvacijos laipsnio, būtina ją stiprinti nuolat stebint mokymo situaciją (Helmke, 2012; Williams, Burden, 1997). Motyvacijos 
stiprinimo veiksniai gali būti labai įvairūs. Nors mokomieji dalykai skiriasi, vienas svarbiausių dalykų mokymo procese - pasirinkti tinkamas mokymo priemones. Mokant anglų kalbos dažniausiai pasirenkamos tokios tradicinès priemonès kaip vadovėlis, lenta, muzikos grotuvas ir žodynai, nors dauguma autorių pripažįsta, kad tradicinių mokymo priemonių nebeužtenka, norint sėkmingai perteikti žinias (Vaitonytė, 2007, 40). Nuolat tobulejjant informacinèms ir komunikacijos technologijoms, atsiveria nemažai galimybių patobulinti anglų kalbos mokymui skirtos medžiagos pristatymą. Tokios inovatyvios mokymo priemonès kaip kompiuteriai, internetas, interaktyviosios lentos, multimedijos projektorius, išmanieji telefonai ir kitos padeda pateikti besimokantiesiems ịvairesnę informaciją ir patraukliai ją pristatyti. Inovatyvios mokymo priemonès skatina besimokančiųjų tarpusavio, taip pat besimokančiụjų ir mokytojų bendravimą, taip didindamos motyvaciją ir gerindamos mokymosi rezultatus (Daukilas, 2007).

Tyrimo objektas - inovatyvių mokymo priemonių ịtaka besimokančiųu motyvacijai skatinti.

Tyrimo tikslas - išanalizuoti naudojamų inovatyvių mokymo priemonių įtaką besimokančiųjų motyvacijai anglų kalbos pratybose.

\section{Tyrimo uždaviniai:}

- nustatyti ir įvertinti inovatyvių ir tradicinių mokymo priemonių naudojimo dažnumą;

- nustatyti ir įvertinti tradicinių ir inovatyvių mokymo priemonių anglų kalbos pratybose poveikị besimokančiųų motyvacijai.

Tyrimo problema keliama probleminiu klausimu: kokios mokymo priemonès daro didžiausią įtaką besimokančiụjų motyvacijai? Analizuojant literatūros šaltinius buvo rasta nemažai inovatyvių priemonių populiarumo tyrimų, tačiau nepavyko aptikti tyrimo, kuriame būtu sugretintos konkrečios inovatyvios ir tradicinès priemonès, panaudojus besimokančiųjų apklausos dèl mokymo priemonių įtakos jų motyvacijai duomenis. Motyvacija ypač plačiai nagrinejjama užsienio kalbų mokymo kontekste. Remiantis išnagrinètais literatūros šaltiniais buvo iškelta hipotezė, kad inovatyvios mokymo priemonès labiau motyvuoja mokytis nei tradicinès.

\section{Tyrimo metodai ir organizavimas}

Siekiant išsiaiškinti inovatyvių mokymo priemonių ịtaką besimokančiųjų motyvacijai anglų kalbos pratybose buvo atliktas tyrimas taikant anketinès apklausos metodą. Tyrimas buvo atliekamas Generolo Jono Žemaičio Lietuvos karo akademijos Užsienio kalbų instituto Kauno užsienio kalbų mokymo skyriuje. Buvo apklausta 50 anglų kalbos kursų klausytojų. Respondentų amžius - nuo 26 iki 50 metų. Tyrimo metu klausytojams buvo išdalytos anketos, ị kurių klausimus jie turèjo atsakyti, vertindami parinktų inovatyvių ir tradicinių priemonių naudojimo dažnumą anglų kalbos pratybose pagal vertinimo skalę nuo 5 (labai dažnai) iki 1 (labai 
retai). Taip pat jie turejjo atsakyti į klausimus, ar šios priemonès yra reikalingos, ir procentais ịvertinti, kiek laiko turètų užimti inovatyvių priemonių naudojimas anglu kalbos pratybose. Šio tyrimo analizėje atsakymai ị šiuos ir kitus klausimus išreikšti procentais (\%). Anketa buvo anoniminè, ją sudare uždaro tipo klausimai. Kadangi buvo apklausiami klausytojai, kuriuos mokè skirtingi dèstytojai, tyrimo rezultatams turejjo įtakos ir tai, kiek ir kokių priemonių naudojo konkretus dėstytojas.

\section{Tyrimo rezultatai}

Klausytojų buvo prašoma atsakyti, kaip dažnai anketoje pateiktos inovatyvios ir tradicinès mokymo priemonès yra naudojamos jų anglų kalbos pratybose. Iš atsakymų paaiškejjo, kad dažniausiai naudojamos inovatyvios priemonès yra multimedijos projektorius ir kompiuteris: $48 \%$ respondentų nurodè šią priemonę kaip labai dažnai, o $28 \%$ - kaip dažnai naudojamą. $34 \%$ klausytojų teige, kad labai dažnai, o $38 \%$ - kad dažnai yra naudojamas internetas. $38 \%$ klausytojų ịvertino kompiuterines programas kaip dažnai naudojamą interaktyvią priemonę anglų kalbos užsièmimuose. $40 \%$ klausytojų nuomone, labai retai naudojami išmanieji telefonai. 38 \% klausytojų teige, kad rečiausiai naudojamas elektroninis žodynas, o $28 \%$ - kad elektroninis paštas (žr. 1 lentelę).

1 lentelė. Inovatyvių mokymo priemonių naudojimo dažnumas anglų kalbos pratybose

\begin{tabular}{|c|c|c|c|c|c|c|}
\hline Vertinimas & $\begin{array}{c}\text { Kompiuterinès } \\
\text { programos }\end{array}$ & $\begin{array}{c}\text { Elektroninis } \\
\text { žodynas }\end{array}$ & Internetas & $\begin{array}{c}\text { Išmanusis } \\
\text { telefonas }\end{array}$ & $\begin{array}{c}\text { Elektroninis } \\
\text { paštas }\end{array}$ & $\begin{array}{c}\text { Multimedijos } \\
\text { projektorius } \\
\text { ir kompiuteris }\end{array}$ \\
\hline Labai dažnai & $8 \%$ & $8 \%$ & $34 \%$ & $10 \%$ & $2 \%$ & $48 \%$ \\
\hline Dažnai & $38 \%$ & $2 \%$ & $38 \%$ & $6 \%$ & $14 \%$ & $28 \%$ \\
\hline Vidutiniškai & $30 \%$ & $16 \%$ & $16 \%$ & $20 \%$ & $20 \%$ & $22 \%$ \\
\hline Retkarčiais & $18 \%$ & $8 \%$ & $8 \%$ & $24 \%$ & $36 \%$ & $2 \%$ \\
\hline Labai retai & $6 \%$ & $4 \%$ & $4 \%$ & $40 \%$ & $28 \%$ & $0 \%$ \\
\hline
\end{tabular}

Dažniausiai naudojamos tradicinės mokymo priemonès, klausytojų nuomone, yra vadovèlis (68 \%), lenta ir rašikliai (38\%), muzikos grotuvas (32\%). Net $14 \%$ klausytojų teige, kad rečiausiai anglų kalbos pratybose naudojamas žodynas (žr. 2 lentelę). 
2 lentelè. Tradicinių mokymo priemonių naudojimo dažnumas anglų kalbos pratybose

\begin{tabular}{|c|c|c|c|c|}
\hline Vertinimas & Lenta ir rašikliai & Žodynas & Muzikos grotuvas & Vadovèlis \\
\hline Labai dažnai & $38 \%$ & $12 \%$ & $32 \%$ & $68 \%$ \\
\hline Dažnai & $42 \%$ & $26 \%$ & $28 \%$ & $12 \%$ \\
\hline Vidutiniškai & $14 \%$ & $28 \%$ & $36 \%$ & $14 \%$ \\
\hline Retkarčiais & $6 \%$ & $20 \%$ & $2 \%$ & $2 \%$ \\
\hline Labai retai & $0 \%$ & $14 \%$ & $2 \%$ & $4 \%$ \\
\hline
\end{tabular}

Klausytojų buvo prašoma atsakyti, kaip jų motyvaciją mokytis skatina nurodytos inovatyvios priemonès. Daugiausiai, net $34 \%$, klausytojų teigè, kad juos labai skatina mokytis įvairios medžiagos pristatymas, naudojant multimedijos projektorių ir kompiuterį. $28 \%$ klausytojų ịvertino internetą kaip inovatyvią priemonę, labai skatinančią mokytis. $18 \%$ klausytojų teigè, kad juos skatina mokytis kompiuterinės programos. Tą pačią priemonę net 50 \% klausytojų ịvertino tik kaip šiek tiek skatinančią mokytis. Elektroninị paštą kaip mažiausiai motyvuojančią inovatyvią priemonę įvertino $22 \%$ klausytojų. $12 \%$ klausytojų neigiamai ịvertino ir išmanujji telefoną (žr. 3 lentelę).

3 lentelè. Klausytojų motyvacijos vertinimas naudojant inovatyvias mokymo priemones

\begin{tabular}{|l|c|c|c|c|c|c|}
\hline \multicolumn{1}{|c|}{ Vertinimas } & $\begin{array}{c}\text { Kompiu- } \\
\text { terinès } \\
\text { programos }\end{array}$ & $\begin{array}{c}\text { Elektro- } \\
\text { ninis } \\
\text { žodynas }\end{array}$ & $\begin{array}{c}\text { Inter- } \\
\text { netas }\end{array}$ & $\begin{array}{c}\text { Išmanusis } \\
\text { telefonas }\end{array}$ & $\begin{array}{c}\text { Elek- } \\
\text { troninis } \\
\text { paštas }\end{array}$ & $\begin{array}{c}\text { Multimedijos } \\
\text { projektorius ir } \\
\text { kompiuteris }\end{array}$ \\
\hline Labai & $18 \%$ & $18 \%$ & $28 \%$ & $14 \%$ & $2 \%$ & $34 \%$ \\
\hline Skatina & $50 \%$ & $30 \%$ & $46 \%$ & $16 \%$ & $12 \%$ & $34 \%$ \\
\hline Nei taip, nei ne & $24 \%$ & $40 \%$ & $22 \%$ & $36 \%$ & $44 \%$ & $26 \%$ \\
\hline Neskatina & $6 \%$ & $10 \%$ & $2 \%$ & $22 \%$ & $20 \%$ & $4 \%$ \\
\hline Visiškai neskatina & $8 \%$ & $2 \%$ & $2 \%$ & $12 \%$ & $22 \%$ & $2 \%$ \\
\hline
\end{tabular}

Su anketoje pateiktu teiginiu „Inovatyvios priemonès man padeda geriau įsisavinti anglų kalbos žinias“ $26 \%$ klausytojų visiškai sutiko, o $48 \%$ - sutiko. Su teiginiu nesutiko tik $4 \%$ klausytojų. Kiti klausytojai šiuo klausimu neturejjo nuomonès (žr. 4 lentelę).

4 lentelè. Anglų kalbos žinių įsisavinimas naudojant inovatyvias priemones

\begin{tabular}{|c|c|}
\hline Vertinimas & Atsakymai \\
\hline Visiškai sutinku & $26 \%$ \\
\hline Sutinku & $48 \%$ \\
\hline Nesu tikras & $11 \%$ \\
\hline Nesutinku & $4 \%$ \\
\hline Visiškai nesutinku & $0 \%$ \\
\hline
\end{tabular}


$\mathrm{Su}$ anketoje pateiktu analogišku teiginiu apie tradicines priemones tik $12 \%$ klausytojų visiškai sutiko, o $42 \%$ klausytojų tiesiog sutiko. Po $2 \%$ klausytojų pažymejjo, kad nesutinka ar visiškai nesutinka su pateiktu teiginiu. Kiti klausytojai šiais klausimais neturèjo nuomonès (žr. 5 lentelę).

5 lentelè. Anglų kalbos žinių įsisavinimas naudojant tradicines priemones

\begin{tabular}{|c|c|}
\hline Vertinimas & Atsakymai \\
\hline Visiškai sutinku & $12 \%$ \\
\hline Sutinku & $42 \%$ \\
\hline Nesu tikras & $42 \%$ \\
\hline Nesutinku & $2 \%$ \\
\hline Visiškai nesutinku & $2 \%$ \\
\hline
\end{tabular}

Respondentų buvo prašoma atsakyti, ar pratybose reikia naudoti tradicines mokymo priemones. $78 \%$ klausytojų atsakè teigiamai. Tik $6 \%$ klausytojų atsakè neigiamai, o $16 \%$ klausytojų neturejo nuomonès (žr. 6 lentelę).

6 lentelė. Tradicinių mokymo priemonių poreikis anglų kalbos pratybose

\begin{tabular}{|c|c|}
\hline Vertinimas & Atsakymai \\
\hline Taip & $78 \%$ \\
\hline Ne & $6 \%$ \\
\hline Nežinau & $16 \%$ \\
\hline
\end{tabular}

Klausytojai taip pat turejo procentais įvertinti, kaip dažnai, jų nuomone, inovatyvios priemonès turètų būti naudojamos anglų kalbos pratybose. Iš pateiktų atsakymu matyti, kad klausytojai sutinka, jog inovatyvios mokymo priemonès yra reikalingos ir turètų būti naudojamos dažniau nei $15 \%$ anglų kalbos pratybų. Net $44 \%$ klausytojų teigè, kad inovatyvios priemonès turètų būti naudojamos 25-50\% pratybų. $34 \%$ klausytojų teigè, kad inovatyvios priemonès turètų būti dar dažniau naudojamos, t. y. 50-75\% anglų kalbos pratybų (žr. 7 lentelę).

7 lentelè. Galimas inovatyvių mokymo priemonių naudojimo dažnumas anglų kalbos pratybose

\begin{tabular}{|c|c|}
\hline Pratybų skaičius & Atsakymai \\
\hline $0-15 \%$ & $0 \%$ \\
\hline $15-25 \%$ & $10 \%$ \\
\hline $25-50 \%$ & $44 \%$ \\
\hline $50-75 \%$ & $34 \%$ \\
\hline $75-100 \%$ & $12 \%$ \\
\hline
\end{tabular}




\section{Tyrimo rezultatụ apibendrinimas}

Atliekant tyrimą buvo siekiama išsiaiškinti, kaip Generolo Jono Žemaičio Lietuvos karo akademijos Užsienio kalbų katedros Kauno užsienio kalbų mokymo skyriaus klausytojai vertina inovatyvių priemonių naudojimą anglų kalbos pratybose ir šių priemonių ịtaką mokymosi motyvacijai skatinti, palyginti su tradicinèmis. Tyrimo rezultatai parodè, kad tokios inovatyvios mokymo priemonès kaip išmanusis telefonas ( $6 \%$ respondentų nurodè, kad naudoja dažnai šias priemones) ar elektroninis paštas (14 \% respondentų nurodè, kad naudoja dažnai šią priemonę) dar nèra populiarios. Lyginant klausytojų atsakymus apie mokymo priemonių naudojimo dažnumą ir klausytojų motyvacijos skatinimą, matyti, kad kai kurių inovatyvių mokymo priemonių vertinimas skiriasi nuo jų motyvacijos mokytis vertinimo. Tokios inovatyvios priemonès kaip kompiuterinès programos, išmanusis telefonas ir ypač elektroninis žodynas, klausytojų nuomone, turètų būti naudojamos dažniau. O multimedijos projektorių, kuris naudojamas dažniausiai, klausytojai vertina kaip mažiau motyvuojanti nei, pavyzdžiui, internetą. Tyrimo rezultatai taip pat parodè, kad klausytojai mokymosi procese labiau vertina tokias inovatyvias mokymosi priemones kaip kompiuterinès programos (50\% respondentų) ir internetas (46\% respondentu). Abi šios priemonès padeda pagyvinti užsièmimus vaizdo medžiaga, kurią galima sukurti ir pateikti naudojant kompiuterines technologijas. Remiantis įvairių autorių tyrimų duomenimis (Daukilas, Teresevičienè, 2007; Vaitonytė, 2007; Girdzijauskienė ir kt., 2010), klausytojų teigiamą interneto vertinimą galima paaiškinti jame esančios informacijos gausa. Šia informacija klausytojai gali patogiai ir greitai naudotis mokydamiesi anglų kalbos, rengdamiesi pratyboms. Elektroninis paštas buvo ịvertintas kaip mažiausiai motyvuojanti mokytis inovatyvi priemoné (2\%), ir tai rodo, kad klausytojai, kaip ir dėstytojai, dažniausiai ji naudoja savo asmeninėms reikmėms, o ne mokymosi procese (Daukilas, Teresevičiené, 2007; Vaitonytė, 2007).

Analizuojant tradicinių mokymo priemonių naudojimo dažnumą ir ryšį su besimokančiųjų motyvacija matyti, kad labai dažnai naudojamos tradicinės priemonès mažiau motyvuoja klausytojus mokytis. Tokios priemonès kaip lenta ir rašikliai (38 \%), taip pat vadovèlis (42\%) įvertintos kaip gerokai mažiau motyvuojančios klausytojus. Tradicinè priemonè, kuri klausytojus pakankamai motyvuoja mokytis, tačiau nèra gana dažnai naudojama, yra muzikos grotuvas. Šị rezultatą galèjo lemti tai, kad anglų kalbos pratybose muzikos grotuvas dažniausiai naudojamas tam tikroms vadovèlio užduotims atlikti ir retai - kitiems tikslams.

Apibendrinus tyrimo inovatyvių ir tradicinių priemonių įtakos klausytojų motyvacijai mokytis rezultatus galima teigti, kad inovatyvios priemonés jiems padeda geriau mokytis.

Tyrimo rezultatai taip pat atskleide, kad klausytojai vertina ir tradicines mokymo priemones ir nenoretų visiškai jų pakeisti kitomis. Šie rezultatai iš esmès patvirtina kitų autorių nuomonę, kad tradicinių priemonių visiškai atsisakyti 
netikslinga, nes jos sudaro galimybę besimokančiajam ir dèstytojui tiesiogiai bendrauti (Vaitonytė, 2007; Kennedy ir kt., 2008).

Rezultatai rodo, kad dauguma (48-74 \%) klausytojų yra už inovatyvių priemonių naudojimą pratybų metu. Gauti duomenys patvirtina kitų autorių nuomonę (Daukilas, Teresevičienè, 2007; Vaitonytė, 2007; Gedvilienè ir kt., 2008), kad naudojamos ịvairios technologijos motyvuoja besimokančiuosius ir yra jiems naudingos mokymosi procese (Vaitonyte, 2007; Gedvilienè ir kt., 2008).

Šio tyrimo rezultatai patvirtino kitų autorių išvadas (Daukilas, Teresevičienè, 2007; Vaitonyte, 2007; Girdzijauskienè ir kt., 2010), kad naudojamos inovatyvios priemonès, ypač kompiuterinès programos ir internetas, padeda sudominti ir motyvuoti besimokančiuosius. Naudojantis šias priemones besimokantysis gali atlikti sudètingesnes užduotis ir veiklas, o mokytojas - siekti geresnių mokymo rezultatų, nes padidejja atitinkamų užduočių ir veiklų pasirinkimo spektras. Siekiant taikyti inovatyvias priemones sėkmingame mokymosi procese, besimokančiajam turi būti sudarytos galimybės išmokti jomis naudotis ir, be abejo, turèti tinkamas tam sąlygas. Dėstytojams taip pat turi būti suteikta pakankamai informacijos apie inovatyvių priemonių taikymą ugdymo procese (Girdzijauskienè ir kt., 2010).

Apibendrinant ịvairiu autorių nuomones ir atlikto tyrimo rezultatus galima daryti išvadą, kad, mokant anglų kalbos, taikant tik tradicinius metodus ir priemones, orientuotas ị faktinių žinių perdavimą, geresnių rezultatų pasiekti nepavyks. Atliktos analizès ir tyrimai skatina mokymo proceso metu ieškoti naujų sprendimų, siekiant perteikti žinias ir padidinti besimokančiųų motyvaciją. Tai daryti padeda inovatyvios priemonès - internetas, kompiuterinès programos, multimedijos ir pan. (Girdzijauskienè ir kt., 2010; Pečiuliauskienè, Rimeikia, Kleniauskas, 2007).

\section{Išvados}

1. Atlikto tyrimo rezultatai atskleide, kad:

- tradicinès mokymo priemonès anglu kalbos pratybose yra naudojamos dažniau nei inovatyvios;

- iš inovatyvių mokymo priemonių dažniausiai naudojamos multimedijos projektorius ir internetas, rečiausiai - mobilusis telefonas, elektroninis paštas ir elektroninis žodynas;

- galima teigti, jog inovatyvios priemonès klausytojus labiau motyvuoja mokytis nei tradicinès;

- $44 \%$ klausytojų nuomone, inovatyvios mokymo priemonès turètų būti naudojamos dažniau nei $25 \%$ pratybų;

- kaip labiausiai motyvuojančios inovatyvios mokymo priemonès buvo ịvertintas internetas ( $28 \%$ ), multimedijos projektorius ir kompiuterinès programos (34\%);

- klausytojų nuomone, tradicinių mokymo priemonių nereikètų visiškai atsisakyti. 
2. Iškelta hipotezè, kad inovatyvios mokymo priemonès labiau motyvuoja mokytis nei tradicinès, iš esmès pasitvirtino:

- $74 \%$ klausytojų nuomone, inovatyvios priemonès teigiamai veikè jų motyvaciją mokytis;

- klausytojų nuomone, labiau motyvuoja mokytis inovatyvios (74 \%) mokymo priemonès nei tradicinès (54\%).

\section{Literatūros sąrašas}

Daukilas, S. (2007). Vertybinių nuostatų diegimas panaudojant IT priemones. Pedagogu kompetenciju tobulinimas integruojant informacines komunikacines technologijas i ugdymo procesa. Vilnius: Pedagogų profesinès raidos centras, 23-36.

Daukilas, S., Teresevičienè, M. (2007). Internetinių technologijų panaudojimo ugdymo procese galimybės. Pedagogu kompetenciju tobulinimas integruojant informacines komunikacines technologijas i ugdymo procesa. Vilnius: Pedagoginès profesinès raidos centras, 75-96.

Gedvilienė, G., Laužackas, R., Lileikienė, T., Mačianskienė, N., Sabaliauskas, T., Sajienė, L., Stasiūnaitè, E., Teresevičienė, M., Tūtlys, V. (2008). Ko reikia šiuolaikiniam mokytojui? Aktualus mokytoju kvalifikacijos tobulinimo turinys. Vilnius: Lietuvos pramonès prekybos ir amatų rūmų asociacija.

Girdzijauskienė, R., Gudynas, P., Jakavonyte, D., Jevsikova, T. (2010). Inovatyviu mokymo(si) metodu ir IKT taikymas. I knyga. Vilnius: Ugdymo plètotès centras. Prieiga per internetą: http://www.inovacijos_upc.smm.lt/upload/1\%20knyga.pdf. Žiūrèta $2017 \mathrm{~m}$. birželio $16 \mathrm{~d}$.

Helmke, A. (2012). Pamokos kokybe ir mokytojo profesionalumas. Vilnius: Standartų spaustuvè.

Kennedy, G. E., Judd, T. S., Churchward, A., Gray, K., Krause, K. (2008). First year students' experiences with technology: Are they really digital natives? Prieiga per internetą: https://ajet.org.au/index.php/AJET/article/view/1233. Žiūrèta $2017 \mathrm{~m}$. liepos $17 \mathrm{~d}$.

Pečiuliauskienė, P., Rimeikia, A., Kleniauskas, L. (2007). Modulio „Informacinių technologijų taikymas studijų procese" mokymo metodų aprašas. Inovatyviu šiuolaikiniu studiju technologiju kriterijai ir aprašas. Marija Barkauskaitè, Vida Gudžinskienè. Vilnius: Petro ofsetas, 120-141.

Vaitonytė, G. (2007). IT priemonių taikymas mokymosi motyvacijai stiprinti. Pedagogu kompetenciju tobulinimas integruojant informacines komunikacines technologijas i ugdymo procesa. Vilnius: Pedagogų profesinès raidos centras, $37-44$.

Williams, M., Burden, R. L. (1997). Psychology for Language Teachers. Cambridge: CUP. 


\title{
INNOVATIVE TEACHING TOOLS IN THE ENGLISH CLASSROOM
}

\author{
Renata Skučienè \\ General Jonas Žemaitis Military Academy of Lithuania
}

\section{Summary}

Innovative teaching tools stimulate communication among learners and between learners and teachers, thereby enhancing motivation and improving learning outcomes. The purpose of the study was to analyze the influence of the use of innovative teaching tools on learner motivation in the English language classes. For the purpose, a survey was carried out using questionnaire survey and statistical data analysis methods. The study was conducted at General Jonas Žemaitis Military Academy of Lithuania, Foreign Language Centre, Kaunas English Language Teaching Section. Fifty English students with different levels of English knowledge were interviewed. The results of the research revealed that traditional teaching tools in English lessons are used more frequently than the innovative ones, multimedia projectors and the Internet are used most commonly and the mobile phone, the e-mail and the electronic dictionary are used most rarely. Based on the results of the research, it can be stated that the use of innovative tools motivates listeners to learn more than the use of the traditional ones. According to the learners, innovative teaching tools should be used at more than $15 \%$ of the lessons. The most motivating innovative teaching tools were found to be the Internet, multimedia projectors and computer programs. On the other hand, learners stated that traditional teaching tools should not be refused completely. The hypothesis that innovative training tools motivate learning more than the traditional ones was proved by the learners as follows: $26 \%$ fully agreed and $48 \%$ agreed with this statement, whereas $12 \%$ fully agreed and $42 \%$ agreed with the statement that traditional tools are more motivating.

Keywords: innovative teaching tools, traditional teaching tools, learning motivation 


\section{AUTORIAUS LYDRAŠTIS}

Autoriaus vardas, pavardè: Renata Skučienè

Mokslo laipsnis ir vardas: humanitarinių mokslų magistras

Darbo vieta ir pareigos: Generolo Jono Žemaičio Lietuvos karo akademijos užsienio kalbų katedros Kauno užsienio kalbų mokymo skyrius, užsienio k. dėstytoja

Autoriaus mokslinių interesų sritys: dabartinė anglų kalba, anglų kalbos gramatika, užsienio kalbų dèstymo didaktika, inovatyvios mokymo priemonès

Telefonas ir el. pašto adresas: +370 5210 3490, renata.skuciene@mil.lt

\section{AUTHOR'S COVER LETTER}

Author's name, surname: Renata Skučienè

Academic degree and name: Master of Arts in Humanities

Workplace and position: General Jonas Žemaitis Military Academy of Lithuania, Foreign Language Centre, Lecturer

Author's research interests: modern English, English grammar, foreign language teaching methods, innovative teaching tools

Telephone and e-mail address: +370 5210 3490, renata.skuciene@mil.lt 